\title{
Opposing Regulation of Human Alveolar Type II Cell Differentiation by Nitric Oxide and Hyperoxia
}

\author{
LINDSAY C. JOHNSTON, LINDA W. GONZALES, RICHARD T. LIGHTFOOT, SUSAN H. GUTTENTAG, \\ AND HARRY ISCHIROPOULOS \\ Department of Pediatrics [L.C.J., L.W.G., R.T.L., S.H.G., H.I.], Division of Neonatology, Children's Hospital of Philadelphia, \\ Philadelphia, Pennsylvania, 19104
}

\begin{abstract}
Clinical trials demonstrated decreasing rates of bronchopulmonary dysplasia in preterm infants with hypoxic respiratory failure treated with inhaled nitric oxide (iNO). However, the molecular and biochemical effects of iNO on developing human fetal lungs remain vastly unknown. By using a well-characterized model of human fetal alveolar type II cells, we assessed the effects of iNO and hyperoxia, independently and concurrently, on NO-cGMP signaling pathway and differentiation. Exposure to iNO increased cGMP levels by 40 -fold after $3 \mathrm{~d}$ and by 8 -fold after $5 \mathrm{~d}$ despite constant expression of phosphodiesterase-5 (PDE5). The levels of cGMP declined significantly on exposure to iNO and hyperoxia at 3 and $5 \mathrm{~d}$, although expression of soluble guanylyl cyclase (sGC) was sustained. Surfactant proteins B and C (SP-B, SP-C) and thyroid transcription factor (TTF)-1 mRNA levels increased in cells exposed to iNO in normoxia but not on exposure to iNO plus hyperoxia. Collectively, these data indicate an increase in type II cell markers when undifferentiated lung epithelial cells are exposed to iNO in room air. However, hyperoxia overrides these potentially beneficial effects of iNO despite sustained expression of sGC. (Pediatr Res 67: 521-525, 2010)
\end{abstract}

A lveolar type II cells are critical for normal lung development as the source of pulmonary surfactant. The components of surfactant, which are necessary to construct a surface-active film at the alveolar surface thereby preventing alveolar collapse, are developmentally regulated. Specifically, surfactant proteins B and C (SP-B and SP-C) undergo complex regulation involving transcriptional and posttranscriptional events occurring through the second and third trimesters of human gestation (1-4). Premature infants are at high risk for developing RDS, in part, because of interruption of this process. Despite advances in obstetrical and neonatal management, including antenatal glucocorticoid therapy and postnatal surfactant administration, RDS remains a major cause of morbidity and mortality in preterm infants (5), often because

Received July 1, 2009; accepted January 6, 2010.

Correspondence: Harry Ischiropoulos, Ph.D., Children's Hospital of Philadelphia and the University of Pennsylvania, 417 Abramson Pediatric Research Center 34th Street and Civic Center Blvd, Philadelphia, PA 19104-4318; e-mail: ischirop@mail.med.upenn.edu

Supported by the Gisela and Dennis Alter Chair in Pediatric Neonatology, the Joseph Strokes Jr Investigator program at the Children's Hospital of Philadelphia, the Center of Excellence in Environmental Toxicology Grant ES013508 NIEHS, and NIH Grant HL059959. it is a risk factor for the development of bronchopulmonary dysplasia (BPD). There remains great interest in identifying additional therapeutic agents that will enhance alveolar type II cell maturation and surfactant production to further reduce the risk of RDS and BPD.

Nitric oxide (NO), a versatile endogenous mediator of vascular relaxation and signaling, has been effective in the treatment of term infants with pulmonary hypertension (6-8). The association of BPD with vascular pruning and pulmonary hypertension sparked interest in using NO to improve outcomes in preterm infants with hypoxic respiratory failure who are at risk of developing BPD. Until recently, clinical trials revealed mixed results (9-12). However, two large multicenter randomized clinical trials indicated beneficial effects of NO in preterm infants. Ballard et al. (13) reported significantly decreased rates of BPD and decreased need for supplemental oxygen in infants treated with inhaled NO (iNO). Kinsella et al. (14) also reported decreased BPD rates in infants with birth weight 1000-1250 $\mathrm{g}$, despite no overall difference in rates of BPD or death in the entire study population.

Studies performed in animal models revealed beneficial effects of iNO in alveolar epithelial physiology. The iNO preserves airway structure and function, enhances development of alveolae (15), improves lung compliance and growth $(16,17)$, decreases early lung inflammation and oxidant stress $(18,19)$, and increases surfactant mRNA and protein levels (17,20-24). Endogenously produced by alveolar type II cells, NO participates in the transition from fluid-filled to airbreathing lungs at birth (25). Despite these recognized beneficial effects of iNO in animal models, the molecular effects of exogenous NO have not been well characterized in human fetal lung.

Alveolar type II cells perform many critical functions that include production of pulmonary surfactant, transport of water and ions across the epithelium barrier, production of trophic factors and molecules that modulate inflammatory responses, and regeneration of type I cells on injury (1-3). Alveolar type

\footnotetext{
Abbreviations: PGC, pepsinogen C; PDE5, phosphodiesterase 5; sGC, soluble guanylyl cyclase; SP-B (C), surfactant protein B (C); TTF-1, thyroid transcription factor-1
} 
II cells differentiate from precursor epithelial cells during the second half of human gestation. Previously, we developed and extensively characterized an in vitro model of differentiation of type II cells by exposing isolated epithelial cells derived from human fetal lung explants to glucocorticoid and/or cAMP in serum-free media $(26,27)$. Type II cell differentiation in this model is characterized by increased phosphatidylcholine synthesis, induction of SP synthesis, formation of lamellar bodies, and secretion of surface-active surfactant. This model has been valuable for exploring factors and genes, which regulate the differentiation of parenchymal epithelial cells to type II pneumocytes $(26,27)$. In this study, this well-defined model system was used to test the hypothesis that NO will induce the differentiation of human fetal alveolar type II cell and counter the potential harmful effects of hyperoxia. Experiments also examined for the first time the expression of the enzymes that mediate the NO response, specifically the NOcGMP signaling pathway in human fetal type II cell cultures. Overall, the data provided new insights on the potential functions of $\mathrm{NO}$ in the developing lung and a mechanistic rationale for the use of iNO in the treatment of extremely preterm infants at risk for BPD.

\section{MATERIALS AND METHODS}

Cell culture. Enriched populations of epithelial cells from secondtrimester (16-24 wk gestation) human fetal lung tissue were obtained from Advanced Bioscience Resources, Inc. (Alameda, CA) under Institutional Review Board-approved protocols and were processed as described previously (26). After overnight culture, attached cells remained in serum-free Waymouth medium for $3 \mathrm{~d}$. Next, the cells were cultured in $1 \mathrm{~mL}$ of serum-free Waymouth medium alone (control) or with $10 \mathrm{nM}$ dexamethasone $+0.1 \mathrm{mM} 8$-bromo-cAMP and $0.1 \mathrm{mM}$ isobutylmethylxanthine (DCI) for $5 \mathrm{~d}$ to promote alveolar type II cell differentiation.

During the process of differentiation, cells were cultured at room air temperature in normoxia plus $5 \% \mathrm{CO}_{2}$ in a standard incubator (control) or in one of three test conditions [normoxia plus 20 ppm NO (Matheson Tri-Gas, Bridgeport, NJ), 95\% oxygen alone, or $95 \%$ oxygen plus $20 \mathrm{ppm}$ NO] in a Proox Model 110 chamber (BioSpherix, Redfield, NY) to maintain stable concentrations of oxygen, $\mathrm{CO}_{2}$, and NO. Because of the limited number of cells generated from each fetal lung tissue, only one experimental condition and a corresponding air-exposed control were analyzed at a time. This experimental design also accounts for biologic variance derived from the different human fetal lung tissues. The difference between the experimental treatment condition and the corresponding control group was used to determine the statistical significance of the data. Therefore, the data were presented as fold change compared with the corresponding air-exposed group.

cGMP enzyme immunoassay and NO metabolite analysis. cGMP and NO-derived metabolites were quantified by established methodologies described previously (28).
DNA analysis. DNA concentration was measured using fluorimetry with Hoechst dye (Molecular Probes, Eugene, OR). The standard curve of DNA fluorescence units was used to determine sample DNA concentration that was normalized to room air controls.

Real-time reverse transcriptase polymerase chain reaction. The two-step PCR protocol was performed as detailed elsewhere (29).

Western blot analysis. Immunoblotting for SP-B, pepsinogen C (PGC), soluble guanylyl cyclase (sGC), phosphodiesterase 5 (PDE 5), and glyceraldehyde 3-phosphate dehydrogenase (GAPDH) was performed using previously described procedures (3).

Statistical analysis. Results are given as mean \pm SEM. To determine the statistical significance, we used aired $t$ tests (performed using GraphPad Prism 4.00; GraphPad, San Diego, CA). All protein results were normalized to GAPDH, and RNA results were normalized to $18 \mathrm{~s}$ rRNA.

\section{RESULTS}

Cellular responses to $\mathrm{NO}$ and hyperoxia. Cells cultured in hyperoxia exhibited altered viability compared with cells cultured in normoxia reflected by protein and DNA levels. Total protein recovered after $5 \mathrm{~d}$ of hyperoxia, with or without $\mathrm{NO}$, was significantly decreased (hyperoxia $0.70 \pm 0.06$, hyperoxia plus NO $0.50 \pm 0.04$, values represent percent of normoxia control value; $n=15$ for normoxia and $n=4$ for hyperoxia and hyperoxia plus NO; $p<0.05$ ). A modest but insignificant decrease in protein recovery from the cells exposed to normoxia plus NO $(0.73 \pm 0.09, n-3 ; p=\mathrm{NS})$ was noted. Total cellular DNA recovery decreased moderately in cells exposed to normoxia plus NO $(0.44 \pm 0.02)$, hyperoxia plus NO $(0.73 \pm 0.4)$, and hyperoxia alone $(0.64 \pm 0.17)$ when compared with normoxia controls (values represent percent of normoxia control value; $n=11$ for normoxia and $n=3$ for all other exposures; $p=\mathrm{NS}$ ). These results are consistent with the known toxicity of hyperoxia and the duality of $\mathrm{NO}$ as both a contributor to cell toxicity and a protector of cell viability (30). The effects of NO in cell survival are a function of duration and level of NO exposure and the concomitant exposure to hyperoxia (30). Consequently, all assays were performed using equal amounts of total protein, and densitometry-based assays were normalized to well-recognized housekeeping genes and proteins.

Activation of sGC and production of cGMP directly report on the delivery and utilization of iNO after exposure. The levels of cGMP were quantified in cells after 3 and $5 \mathrm{~d}$ of culture (Fig. 1A). A significant elevation in cGMP levels occurred on d 3 in both the NO-exposed groups when compared with controls in normoxia and hyperoxia alone. How-
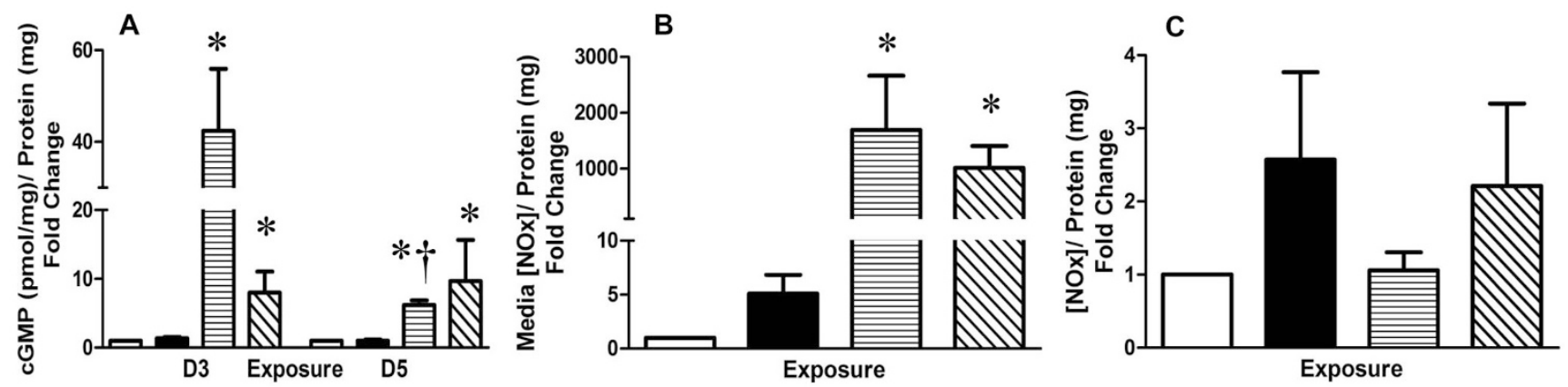

Figure 1. Panel A, cGMP in cell lysates from d 3 and 5 DCI-treated cells. Panel B and $C$, stable NO metabolites in cell media $(B)$ and cell lysates $(C)$. Exposures include: normoxia $(\square)$, hyperoxia $(\square)$, normoxia plus NO (目), or hyperoxia plus NO $(\mathbf{\nabla})$; ${ }^{*} p<0.05$ compared with normoxia on d 3 and ${ }^{\dagger} p<0.05$ compared with corresponding treatment group on $\mathrm{d} 3, n=4$ for all treatment groups. 
ever, at $\mathrm{d} 3$ the levels of cGMP were significantly lower in the iNO plus hyperoxia-exposed cells compared with cells exposed to iNO under normoxic conditions. Moreover, the cGMP levels in the NO-treated groups (both normoxia and hyperoxia) decreased significantly after $5 \mathrm{~d}$ of exposure, despite continuous exposure of the cells (Fig. 1A).

The levels of stable products of NO metabolism were also significantly elevated in the media from cells cultured in DCI media and exposed to NO, with or without hyperoxia (Fig. $1 B)$. However, no difference was detected in the cell lysates (Fig. 1C). Therefore, NO was delivered to the cells, and a corresponding activation of sCG accompanied the exposure.

Expression of $s G C$ and $P D E$ 5. The changes in cGMP levels prompted the investigation of the levels of sGC, the molecular target of NO, and the enzyme responsible for cGMP production. No significant differences in the expression of sGC were measured between exposure groups and the corresponding air-exposed controls on d 3 and 5 (Fig. 2). The expression of PDE5, the major enzyme responsible for the metabolism of cGMP, was also assessed. Similarly, the levels of PDE5 did not vary significantly in the three treatment groups compared with corresponding air-exposed controls (Fig. 3).

Thyroid transcription factor and SP $m R N A$ with iNO and hyperoxic exposure. Real-time RT-PCR revealed increased expression of type II cell markers on d 5 in cells exposed to normoxia plus NO. Cells cultured with normoxia plus iNO had more than 2-fold increase in SP-B mRNA levels (Fig. 4A) and more than 10-fold increase in SP-C mRNA levels (Fig. $4 B$ ) compared with normoxia controls. Hyperoxia alone had no effect on SP-B or SP-C RNA. The effect of iNO on SP-B and SP-C mRNA did not extend to cells cultured in hyperoxia plus NO. The mRNA for thyroid transcription factor (TTF)-1, an essential transcription factor regulating SP synthesis, increased 5-fold in cells exposed to normoxia plus iNO (Fig. $4 C)$. This increase was not apparent in cells exposed to iNO plus hyperoxia.

Type II cell markers with iNO and hyperoxia. Mature SP-B protein was quantified by immunoblotting after exposure to various gas conditions (Fig. 5A). As expected, a significant increase in mature SP-B was detected in cells cultured with the DCI media compared with cells cultured in control media (not shown). The SP-B protein levels were not significantly different in cells exposed to normoxia plus iNO compared with normoxia controls, despite the significant in-
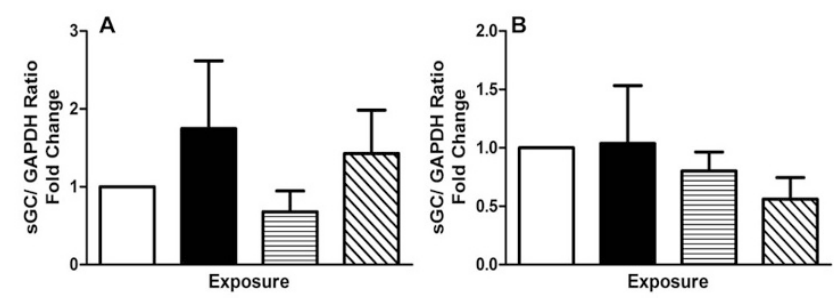

Figure 2. Near-infrared quantification of sGC levels in cells exposed to various gases in DCI media at d 3 (Panel A) and at d 5 (Panel B). Exposure conditions: normoxia $(\square)$, hyperoxia $(\square)$, normoxia plus NO (局), or hyperoxia plus NO (\$).
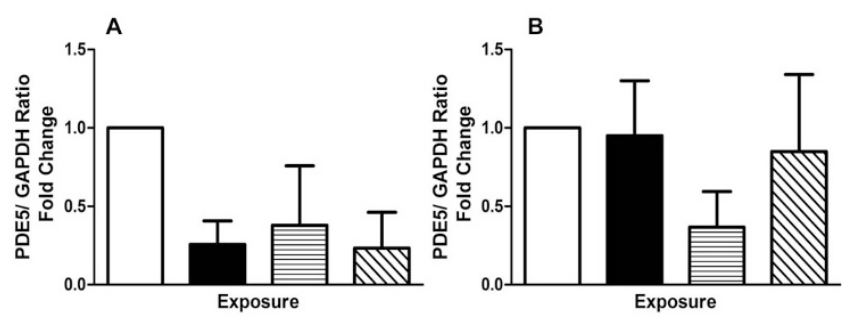

Figure 3. The levels of PDE5 were quantified by western blotting and near-infrared detection at d $3($ Panel $A)$ and d 5 (Panel B). Exposure groups: normoxia $(\square)$, hyperoxia $(\square)$, normoxia NO (冒), or hyperoxia plus NO (\$).

crease in SP-B mRNA. Mature SP-B levels declined by $\sim 80 \%$ in cells exposed to hyperoxia compared with normoxia controls (Fig. 5B). Exposure to iNO in the presence of hyperoxia did not prevent the decline in the levels of SP-B. The levels of PGC, an enzyme involved in SP-B posttranslational proteolytic processing (31), were not significantly altered in the different groups compared with normoxia controls (data not shown).

\section{DISCUSSION}

The iNO has been proven to be useful in the treatment of a variety of respiratory diseases of neonates and adults $(6,7,13,14)$. Motivated by the encouraging results of the most recent clinical trials in neonates, we explored for the first time the responses of human fetal alveolar epithelial cells to iNO under normoxic and hyperoxic conditions. Because the production of surfactant is critically important for normal lung development, we hypothesized that NO/cGMP-induced differentiation of alveolar type II cells might contribute to the pulmonary benefits found in preterm infants treated with NO. By using a well-established in vitro model of fetal alveolar type II cell differentiation, the data revealed opposing regulatory functions of hyperoxia and iNO in the differentiation of human fetal type II pneumocytes.

By quantifying the levels of cGMP, the data indicated that exposure to iNO results in the activation of sGC. The activation of sGC and production of cGMP is one of the major pathways by which NO influences a variety of biologic functions including cellular differentiation (32-34). The data also document for the first time that $\mathrm{sGC}$ is expressed by human fetal type II pneumocytes and, interestingly, the expression is maintained during hyperoxia. Previously, sGC and PDE5 were shown to increase during the perinatal period in rodents and were thought to be important in the transition to air breathing $(35,36)$. However, the NO-stimulated activation of sGC and resultant production of cGMP significantly declined in the presence of hyperoxia. The diminished response to iNO in the presence of hyperoxia is not explained by a decline in the levels of sGC (Fig. 2). The decrease in cGMP levels on $d$ 3 of exposure to NO plus hyperoxia is also not derived from an increase in PDE5 protein, the main lung PDE that removes cGMP, the expression of which is actually decreased (Fig. 3). The decline in cGMP levels may be due to inactivation of sGC or the reaction of NO with superoxide or other radical intermediates formed during hyperoxic exposures. It has been 
A

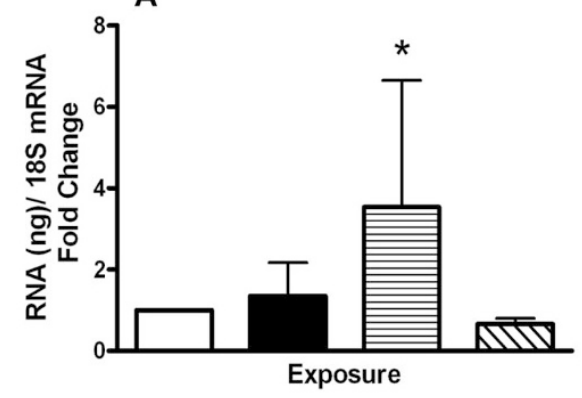

B

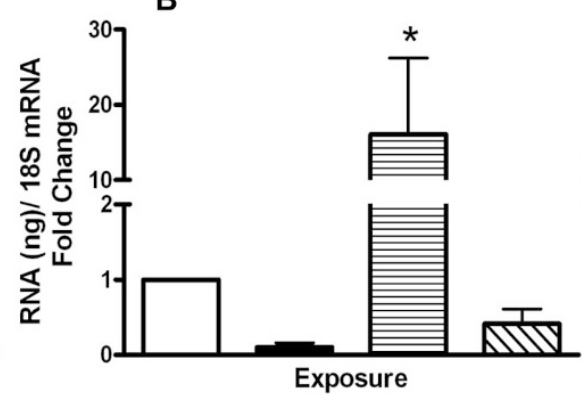

C

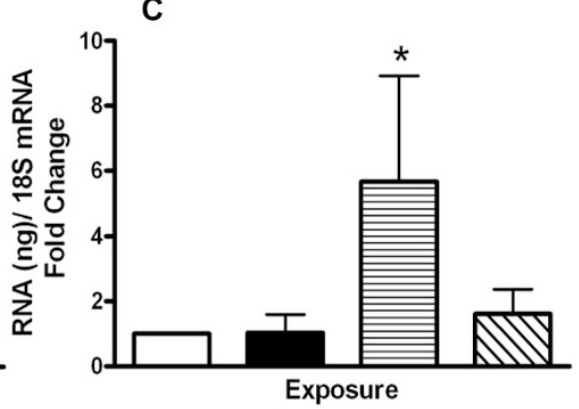

Figure 4. mRNAs for type II cell SP-B $(A)$, SP-C $(B)$, and TTF-1 $(C)$ were measured after $5 \mathrm{~d}$ of culture in DCI media and normoxia ( $\square$ ), hyperoxia ( $\square$ ), normoxia plus NO (冒), or hyperoxia plus NO $(\mathbf{\nabla}) ; * p<0.05, n=3$ for all treatment groups.
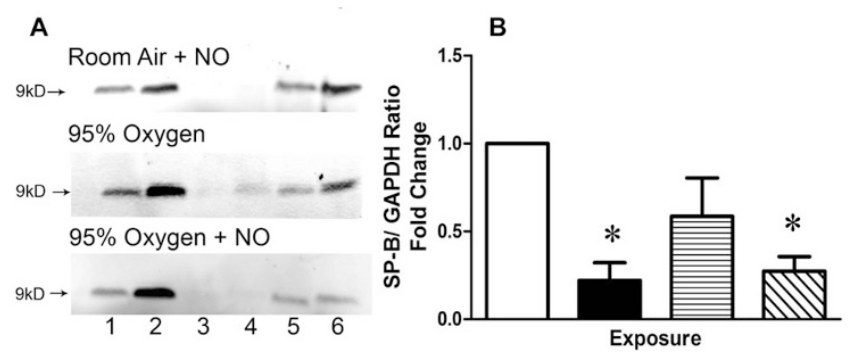

Figure 5. Panel A, Representative SP-B blots. Lanes 1 and 2, normoxia controls with DCI media at d 3 and 5, respectively; Lanes 3 and 4, cells exposed to respective gases as indicated without DCI media at d 3 and 5; Lanes 5 and 6, cells exposed to respective gases as indicated with DCI media at $\mathrm{d} 3$ and 5, respectively. Panel B, SP-B protein levels normalized to GAPDH loading controls after $5 \mathrm{~d}$ of culture in DCI media and either normoxia $(\square)$, hyperoxia ( $\square$ ), normoxia plus NO (司), or hyperoxia plus NO $(\mathbf{\nabla})$; data are expressed as percent of the corresponding normoxia control * $p<0.05, n=$ 5 for all treatment groups.

relatively well documented that hyperoxia increases the production of superoxide and other radicals and that exposure to hyperoxia and iNO alters the reactive nitrogen species formed in rodent lungs $(37,38)$. Evidence for the formation of reactive nitrogen species derived from iNO are also present in the plasma of premature infants exposed to hyperoxia with or without iNO $(37,38)$. Consistent with these findings are the documentation that hyperoxia decreased intracellular cGMP levels in ovine fetal pulmonary artery smooth muscle cells (39). Compared with $d 3$, a significant decline in the levels of cGMP was noted on d 5 despite continuous exposure to iNO. The unexpected decline in cGMP levels after $5 \mathrm{~d}$ of iNO exposure may be explained by decreased responsiveness of sGC after prolonged iNO exposure despite stable protein levels similarly to the suggested tolerance induced by the use of systemic vasodilators (34). Alternatively, it may indicate a rapid non-PDE5-regulated consumption of cGMP for signaling or other regulatory functions.

Significant increases in SP-B, SP-C, and TTF-1 mRNA were measured in cells treated with normoxia plus NO. This suggests that either more cells are differentiating to a type II phenotype or that increased levels of these products are being made by existing type II cells. Interestingly, these changes were not observed in conditions of hyperoxia plus NO, suggesting that high levels of oxygen may oppose the beneficial effects of NO. The levels of mature SP-B increased in cells treated with hormones but not on exposure to iNO despite increased levels of SP-B mRNA.

This study offers a number of new insights in the human fetal lung responses to hyperoxia and NO. As expected, exposure to iNO increased the levels of cGMP by activating sGC. Exposure of premature human fetal epithelial cells to normoxia plus NO leads to increased markers for type II pneumocytes, but these beneficial effects are not observed when NO is administered concomitantly with hyperoxia. Although rodent and other animal models of iNO, such as full-term lamb and premature baboon, demonstrated attenuation of certain aspects of hyperoxic lung injury, the data presented herein indicate that potential beneficial effects of $\mathrm{NO}$ in the maturation and differentiation of alveolar type II cells are mitigated by hyperoxia. Although this study did not explore the dose dependency of the interaction between hyperoxia and NO, the data support that efforts to lower exposure to hyperoxia in the clinical setting may help offset the detrimental effects of hyperoxia and promote the beneficial biologic consequences of iNO.

Acknowledgments. We thank Dr. C. Foster for assistance in study design and reading of the manuscript, P. Wang for preparing the cell monolayers, P. Zhang and L. Varghese for technical assistance, Dr. S.A. Lorch, for statistical support, and Dr. T. Greco and E. Tsika for assistance with figure preparation.

\section{REFERENCES}

1. Ballard PL 1989 Hormonal regulation of pulmonary surfactant. Endocr Rev 10:165181

2. Beers MF, Shuman H, Liley HG, Floros J, Gonzales LW, Yue N, Ballard PL 1995 Surfactant protein B in human fetal lung: developmental and glucocorticoid regulation. Pediatr Res 38:668-675

3. Guttentag SH, Beers MF, Bieler BM, Ballard PL 1998 Surfactant protein B processing in human fetal lung. Am J Physiol 275:L559-L566

4. Solarin KO, Ballard PL, Guttentag SH, Lomax CA, Beers MF 1997 Expression and glucocorticoid regulation of surfactant protein $\mathrm{C}$ in human fetal lung. Pediatr Res 42:356-364

5. Stevenson DK, Wright LL, Lemons JA, Oh W, Korones SB, Papile LA, Bauer CR, Stoll BJ, Tyson JE, Shankaran S, Fanaroff AA, Donovan EF, Ehrenkranz RA, Verter J 1998 Very low birth weight outcomes of the National Institute of Child Health and Human Development Neonatal Research Network, January1993 through December 1994. Am J Obstet Gynecol 179:1632-1639

6. Ehrenkranz RA 1997 Inhaled nitric oxide in full-term and nearly full-term infants with hypoxic respiratory failure. The Neonatal Inhaled Nitric Oxide Study Group. N Engl J Med 336:597-604

7. Clark RH, Kueser TJ, Walker MW, Southgate WM, Huckaby JL, Perez JA, Roy BJ, Keszler M, Kinsella JP 2000 Low-dose nitric oxide therapy for persistent pulmonary hypertension of the newborn. N Engl J Med 342:469-474 
8. Roberts JD Jr, Fineman JR, Morin FC III, Shaul PW, Rimar S, Schreiber MD, Polin RA, Zwass MS, Zayek MM, Gross I, Heymann MA, Zapol WM 1997 Inhaled nitric oxide and persistent pulmonary hypertension of the newborn. N Engl J Med 336:605-610

9. Banks BA, Seri I, Ischiropoulos H, Merrill J, Rychik J, Ballard RA 1999 Changes in oxygenation with inhaled nitric oxide in severe bronchopulmonary dysplasia. Pediatrics 103:610-618

10. Kinsella JP, Walsh WF, Bose CL, Gerstmann DR, Labella JJ, Sardesai S, WalshSukys MC, McCaffrey MJ, Cornfield DN, Bhutani VK, Cutter GR, Baier M, Abman SH 1999 Inhaled nitric oxide in premature neonates with severe hypoxaemic respiratory failure: a randomised controlled trial. Lancet 354:1061-1065

11. Schreiber MD, Gin-Mestan K, Marks JD, Huo D, Lee G, Srisuparp P 2003 Inhaled nitric oxide in premature infants with the respiratory distress syndrome. N Engl J Med 349:2099-2107

12. Van Meurs KP, Wright LL, Ehrenkranz RA, Lemons JA, Ball MB, Poole WK, Perritt R, Higgins RD, Oh W, Hudak ML, Laptook AR, Shankaran S, Finer NN, Carlo WA, Kennedy KA, Fridriksson JH, Steinhorn RH, Sokol GM, Konduri GG, Aschner JL, Stoll BJ, D'Angio CT, Stevenson DK 2005 Inhaled nitric oxide for premature infants with severe respiratory failure. N Engl J Med 353:13-22

13. Ballard RA, Truog WE, Cnaan A, Martin RJ, Ballard PL, Merrill JD, Walsh MC, Durand DJ, Mayock DE, Eichenwald EC, Null DR, Hudak ML, Puri AR, Golombek SG, Courtney SE, Stewart DL, Welty SE, Phibbs RH, Hibbs AM, Luan X, Wadlinger SR, Asselin JM, Coburn CE 2006 Inhaled nitric oxide in preterm infants undergoing mechanical ventilation. N Engl J Med 355:343-353

14. Kinsella JP, Cutter GR, Walsh WF, Gerstmann DR, Bose CL, Hart C, Sekar KC, Auten RL, Bhutani VK, Gerdes JS, George TN, Southgate WM, Carriedo H, Couser RJ, Mammel MC, Hall DC, Pappagallo M, Sardesai S, Strain JD, Baier M, Abman SH 2006 Early inhaled nitric oxide therapy in premature newborns with respiratory failure. N Engl J Med 355:354-364

15. Bland RD, Albertine KH, Carlton DP, MacRitchie AJ 2005 Inhaled nitric oxide effects on lung structure and function in chronically ventilated preterm lambs. Am J Respir Crit Care Med 172:899-906

16. McCurnin DC, Pierce RA, Chang LY, Gibson LL, Osborne-Lawrence S, Yoder BA, Kerecman JD, Albertine KH, Winter VT, Coalson JJ, Crapo JD, Grubb PH, Shaul PW 2005 Inhaled NO improves early pulmonary function and modifies lung growth and elastin deposition in a baboon model of neonatal chronic lung disease. Am J Physiol Lung Cell Mol Physiol 288:L450-L459

17. Ballard PL, Gonzales LW, Godinez RI, Godinez MH, Savani RC, McCurnin DC, Gibson LL, Yoder BA, Kerecman JD, Grubb PH, Shaul PW 2006 Surfactant composition and function in a primate model of infant chronic lung disease: effects of inhaled nitric oxide. Pediatr Res 59:157-162

18. Kinsella JP, Ivy DD, Abman SH 1994 Inhaled nitric oxide improves gas exchange and lowers pulmonary vascular resistance in severe experimental hyaline membrane disease. Pediatr Res 36:402-408

19. Kinsella JP, Parker TA, Galan H, Sheridan BC, Halbower AC, Abman SH 1997 Effects of inhaled nitric oxide on pulmonary edema and lung neutrophil accumulation in severe experimental hyaline membrane disease. Pediatr Res 41:457-463

20. Stuart RB, Ovadia B, Suzara VV, Ross PA, Thelitz S, Fineman JR, Gutierrez JA 2003 Inhaled nitric oxide increases surfactant protein gene expression in the intact lamb. Am J Physiol Lung Cell Mol Physiol 285:L628-L633

21. Salinas D, Sparkman L, Berhane K, Boggaram V 2003 Nitric oxide inhibits surfactant protein B gene expression in lung epithelial cells. Am J Physiol Lung Cell Mol Physiol 285:L1153-L1165

22. McDowell SA, Gammon K, Zingarelli B, Bachurski CJ, Aronow BJ, Prows DR, Leikauf GD 2003 Inhibition of nitric oxide restores surfactant gene expression following nickel-induced acute lung injury. Am J Respir Cell Mol Biol 28:188-198
23. Lee JW, Gonzalez RF, Chapin CJ, Busch J, Fineman JR, Gutierrez JA 2005 Nitric oxide decreases surfactant protein gene expression in primary cultures of type II pneumocytes. Am J Physiol Lung Cell Mol Physiol 288:L950-L957

24. Bhandari V, Johnson L, Smith-Kirwin S, Vigliotta G, Funanage V, Chander A 2002 Hyperoxia and nitric oxide reduce surfactant components (DSPC and surfactant proteins) and increase apoptosis in adult and fetal rat type II pneumocytes. Lung 180:301-317

25. Shaul PW, Afshar S, Gibson LL, Sherman TS, Kerecman JD, Grubb PH, Yoder BA, McCurnin DC 2002 Developmental changes in nitric oxide synthase isoform expression and nitric oxide production in fetal baboon lung. Am J Physiol Lung Cell Mol Physiol 283:L1192-L1199

26. Gonzales LW, Angampalli S, Guttentag SH, Beers MF, Feinstein SI, Matlapudi A, Ballard PL 2001 Maintenance of differentiated function of the surfactant system in human fetal lung type II epithelial cells cultured on plastic. Pediatr Pathol Mol Med 20:387-412

27. Gonzales LW, Guttentag SH, Wade KC, Postle AD, Ballard PL 2002 Differentiation of human pulmonary type II cells in vitro by glucocorticoid plus cAMP. Am J Physiol Lung Cell Mol Physiol 283:L940-L951

28. Munson DA, Grubb PH, Kerecman JD, McCurnin DC, Yoder BA, Hazen SL, Shaul PW, Ischiropoulos H 2005 Pulmonary and systemic nitric oxide metabolites in a baboon model of neonatal chronic lung disease. Am J Respir Cell Mol Biol 33:582-588

29. Foster C, Aktar A, Kopf D, Zhang P, Guttentag S 2004 Pepsinogen C: a type 2 cell-specific protease. Am J Physiol Lung Cell Mol Physiol 286:L382-L387

30. Gow A, Thom SR, Ischiropoulos H 1998 Nitric oxide and peroxynitrite-mediated pulmonary cell death. Am J Physiol Lung Cell Mol Physiol 274:L112-L118

31. Gerson KD, Foster CD, Zhang P, Zhang Z, Rosenblatt MM, Guttentag SH 2008 Pepsinogen $\mathrm{C}$ proteolytic processing of surfactant protein B. J Biol Chem 283:10330-10338

32. Arnold WP, Mittal CK, Katsuki S, Murad F 1977 Nitric oxide activates guanylate cyclase and increases guanosine $3^{\prime}: 5^{\prime}$-cyclic monophosphate levels in various tissue preparations. Proc Natl Acad Sci USA 74:3203-3207

33. Wolin MS, Wood KS, Ignarro LJ 1982 Guanylate cyclase from bovine lung. A kinetic analysis of the regulation of the purified soluble enzyme by protoporphyrin IX, heme, and nitrosyl-heme. J Biol Chem 257:13312-13320

34. Zhao Y, Brandish PE, Ballou DP, Marletta MA 1999 A molecular basis for nitric oxide sensing by soluble guanylate cyclase. Proc Natl Acad Sci USA 96:1475314758

35. Bloch KD, Filippov G, Sanchez LS, Nakane M, De La Monte SM 1997 Pulmonary soluble guanylate cyclase, a nitric oxide receptor, is increased during the perinata period. Am J Physiol 272:L400-L406

36. Sanchez LS, De La Monte SM, Filippov G, Jones RC, Zapol WM, Bloch KD 1998 Cyclic-GMP-binding, cyclic-GMP-specific phosphodiesterase (PDE5) gene expression is regulated during rat pulmonary development. Pediatr Res 43:163-168

37. Lorch SA, Banks BA, Christie J, Merrill JD, Althaus J, Schmidt K, Ballard PL, Ischiropoulos H, Ballard RA 2003 Plasma 3-nitrotyrosine and outcome in neonates with severe bronchopulmonary dysplasia after inhaled nitric oxide. Free Radic Biol Med 34:1146-1152

38. Lorch SA, Munson D, Lightfoot RT, Ischiropoulos H 2004 Oxygen tension and inhaled nitric oxide modulate pulmonary levels of S-nitrosocysteine and 3-nitrotyrosine in rats. Pediatr Res 56:345-352

39. Farrow KN, Groh BS, Schumacker PT, Lakshminrusimha S, Czech L, Gugino SF, Russell JA, Steinhorn RH 2008 Hyperoxia increases phosphodiesterase 5 expression and activity in ovine fetal pulmonary artery smooth muscle cells. Circ Res 102:226233 